Mr Dragan Đukić, potpukovnik, dipl. inž. VP 5003, Novi Sad

Dr Vasilije Mišković,

pukovnik, dipl. inž.

Vojna akademija -ŠNO

Beograd

\section{ANALIZA UTICAJA SNABDEVENOSTI REZERVNIM DELOVIMA NA ISPRAVNOST BORBENIH VOZILA U BORBENIM DEJSTVIMA}

UDC: $623.438-7: 355.415 .2$

Rezime:

Snabdevenost rezervnim delovima znatno utiče na ispravnost borbenih vozila u borbenim dejstvima. Oblik i kvantifikaciju promene gotovosti borbenih vozila, u zavisnosti od verovatnoće popunjenosti rezervnim delovima, moguće je sagledati primenom metode modelovanja i simulacije. Osnovni faktori, koji utiču na gotovost borbenih vozila su: struktura sistema snabdevanja, nivo snabdevanja posmatrane strukture $i$ verovatnoća popunjenosti rezervnim delovima svakog nivoa. Najvažniji rezultati sprovedenog istraživanja su: sagledavanje uticaja osnovnih faktora, prvenstveno snabdevenosti rezervnim delovima na ispravnost borbenih vozila, u borbenim dejstvima.

Ključne reči: rezervni delovi, sistem snabdevanja, borbena vozila, gotovost.

\title{
ANALYSIS OF SPARE PARTS SUPPLIES INFLUENCE ON COMBAT VEHICLE READINESS IN COMBAT OPERATIONS
}

\begin{abstract}
Summary:
Spare parts supplies stocks have a significant influence on proper functioning of combat vehicles in military operations. The form and quantifying of change of military vehicle readiness dependence on spare parts supplies will be reognized by applying the method of modelling and simulation. The basic factors influencing the readiness of combat vehicles are as follows: supply system structure, supply level for a given structure and probability of being supplied by spare parts at all supply levels. The most important result of the research is the knowledge of the basic factors influence, particularly the spare parts supplies influence on the combat vehicle readiness in military operations.
\end{abstract}

Key words: spare parts, supply system, combat vehicle, operational readiness.

\section{Uvod}

Osnovni preduslov za uspešno izvođenje borbenih dejstava je održavanje visokog stepena borbene gotovosti jedinica i vojske u celini na koju ispravnost borbenih vozila, s obzirom na njihov značaj i masovnu upotrebu u vođenju savremenih ratova, ima vrlo bitan uticaj. Zato je potrebno stvoriti preduslove za održava- nje borbenih vozila $\mathrm{u}$ ispravnom stanju, odnosno obezbediti njihovo brzo dovođenje $u$ ispravno stanje u slučajevima nastupanja otkaza ili oštećenja različitih podsklopova, sklopova i agregata, što zahteva preduzimanje različitih radnji održavanja, koje se razlikuju po složenosti tehnologije rada. Uspešnost održavanja umnogome zavisi od raspolaganja potrebnim rezervnim delovima. Zbog nu- 
žnosti da se borbena vozila na kojima je nastao otkaz brzo vrate u eksploataciju, posebno u vreme borbenih dejstava, raspolaganje potrebnim asortimanom i količinama rezervnih delova predstavlja neminovnost. To nameće potrebu da se rezervni delovi nabavljaju, skladište i čuvaju na određenom nivou snabdevanja, $i$ po zahtevu doturaju do krajnjeg korisnika. Pri tome se stalno vrši razmena informacija, koje su pokretač svih radnji održavanja borbenih vozila i snabdevanja rezervnim delovima.

Međutim, raspolaganje zalihama rezervnih delova predstavlja znatan trošak, pa nije svejedno kolike su te zalihe i kako su raspoređene po nivoima snabdevanja i u prostoru. To se naročito odnosi na rezervne delove za tehnička sredstva, čiji je značaj takav da u određenim momentima mogu presudno da utiču na ishod sukoba, kao što su, na primer, borbena vozila. Ako se zna da raspoložive zalihe rezervnih delova imaju znatan uticaj na ispravnost borbenih vozila, a da je za kvalitetno projektovanje sistema snabdevanja i kvalitetno odlučivanje u toku funkcionisanja sistema snabdevanja potrebno poznavanje i oblika i kvantiteta tog uticaja, onda je očigledno da je potrebno da se takav uticaj analizira.

Analizu je moguće sprovesti preko sagledavanja uticaja osnovnih faktora. Izdvajanje relevantnih faktora sistema snabdevanja rezervnim delovima na ispravnost borbenih vozila $\mathrm{u}$ borbenim dejstvima je u funkciji cilja analize. $U$ ovom slučaju, na ispravnost borbenih vozila u borbenim dejstvima utiče nekoliko osnovnih faktora u sistemu snabdevanja rezervnim delovima:
- organizaciona struktura sistema snabdevanja rezervnim delovima;

- nivo u sistemu snabdevanja rezervnim delovima;

- popunjenost rezervnim delovima svakog nivoa snabdevanja;

- pouzdanost toka informacija u informacionom sistemu snabdevanja.

Pod pojmom struktura sistema snabdevanja rezervnim delovima podrazumeva se na koliko nivoa je struktuiran posmatrani sistem, pri čemu se, u ovom slučaju, razmatra četvoronivojski sistem (dva na taktičkom nivou, operativni i strategijski nivo) i tronivojski sistem snabdevanja rezervnim delovima (dva na taktičkom i strategijski nivo snabdevanja).

Ne razmatraju se vrste i količine rezervnih delova po nivoima snabdevanja, nego se operiše verovatnoćom popunjenosti rezervnim delovima po nivoima snabdevanja. Za ovu analizu se pretpostavlja da je informacioni sistem idealan, odnosno da ne postoji mogućnost zaturanja ili gubljenja informacija, nego da funkcioniše upravo onako kako je projektovan.

Prezentirani rezultati u ovom radu odnose se samo na direktan uticaj snabdevenosti rezervnim delovima na ispravnost borbenih vozila u borbenim dejstvima, i to samo za period borbenih dejstava.

U posmatranim sistemima snabdevanja rezervnim delovima ne razmatraju se troškovi zaliha rezervnih delova po nivoima. Analiza je izvršena samo na osnovu proračuna gotovosti za određeni nivo popunjenosti rezervnim delovima, bez analize koliko košta taj nivo gotovosti. 


\section{Model za istraživanje uticaja snabdevenosti rezervnim delovima na ispravnost borbenih vozila u borbenim dejstvima}

Istraživanje uticaja sistema snabdevanja rezervnim delovima na ispravnost borbenih vozila u borbenim dejstvima na realnom sistemu nije moguće. Radi toga pribegava se modelovanju sistema izradom adekvatnih simulacionih modela, koji mogu opisati realni sistem održavanja borbenih vozila, sistem snabdevanja rezervnim delovima i veze koje postoje među tim sistemima. ${ }^{1}$ Te veze su vrlo čvrste i bez njih oba navedena sistema ne bi mogla zadovoljavajuće da funkcionišu. Za potrebe ovog rada korišćen je, kao bazični, model iz [1], koji se zasniva na opštem modelu borbenih dejstava. U ovom radu izvršena je redukcija samo onih rezultata koji se odnose na borbena vozila. Ukupno je posmatrano 521 borbeno vozilo, koliko ih je, po opštem modelu borbenih dejstava, bilo u stanju operativne gotovosti na početku izvođenja borbenih dejstava.

Nezavisna varijabla je verovatnoća zadovoljenja tražnje za rezervnim delovima na svim nivoima snabdevanja, odnosno, verovatnoća popunjenosti rezervnim delovima, a predstavlja odnos između broja odmah realizovanih tražnji za rezervnim delovima i ukupnog broja tražnji. Ova varijabla generiše se prema planu eksperimenta.

Modeli sistema za tronivojsku i četvoronivojsku strukturu sistema dati su u radu „Kvantifikacija i oblik uticaja snabdevenosti rezervnim delovima na ispravnost tehničkih sistema“ objavljenom u Vojnotehničkom glasniku br. 2/2003. Plan eksperimenta je istovetan kao u navedenom radu, s tim da se u ovom radu izdvajaju samo rezultati za jednu grupu sredstava (borbena vozila) $i$ oni se analiziraju.
Zavisna varijabla je operativna gotovost borbenih vozila. Uslovno, gotovost se može odrediti kao odnos srednje vrednosti ispravnih tehničkih sredstava prema ukupnom broju tehničkih sredstava u nekom vremenskom periodu [1]. U ovom radu operativna gotovost se prikazuje kao odnos broja ispravnih borbenih vozila u momentu posmatranja (na kraju 12. dana izvođenja borbenih dejstava, odnosno u 288. času od početka simulacije) i broja ispravnih borbenih vozila na početku izvođenja borbenih dejstava, izraženo u procentualnom obliku.

\section{Plan i rezultati eksperimenta}

Da bi se istražio uticaj svakog od navedenih faktora izvedeni su eksperimenti sa promenom verovatnoće popunjenosti rezervnim delovima po nivoima snabdevanja. Eksperiment je organizovan tako da promena verovatnoće popunjenosti rezervnim delovima po nivoima snabdevanja poprima vrednosti od 0,1 do 0,99 , isključujući vrednost 0,2 , i to tako da:

- na svim nivoima snabdevanja rezervnim delovima promena bude istovetna,

- promena se vrši na jednom posmatranom nivou snabdevanja rezervnim delovima, a na ostalim nivoima ima modelom zadate parametarske vrednosti.

Nakon izvedenih eksperimenata izvršena je statistička obrada broja ispravnih borbenih vozila za svaku grupu eksperimenata, na osnovu čega je formirana tabela, u kojoj su prikazane srednje vrednosti broja ispravnih borbenih vozila na kraju 12. dana borbenih dejstava, odnosno, u 288. času od početka simulacije (po simulacionom vremenu). 
Pregled ispravnosti borbenih vozila na kraju 12. dana borbenih dejstava

\begin{tabular}{|c|c|c|c|c|c|c|c|c|c|c|c|c|c|c|c|c|c|}
\hline \multirow{3}{*}{ 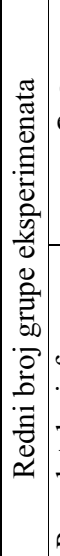 } & \multicolumn{3}{|c|}{$\begin{array}{l}\text { Oznaka } \\
\text { eksperi- } \\
\text { menata }\end{array}$} & \multicolumn{4}{|c|}{$\begin{array}{l}\text { Parametri u } \\
\text { eksperimentu - } \\
\text { vrednost } \\
\text { verovatnoce } \\
\text { popunjenosti } \\
\text { rezervnim } \\
\text { delovima }\end{array}$} & \multirow{2}{*}{\multicolumn{9}{|c|}{ Srednja vrednost broja ispravnih borbenih vozila }} & \multirow{3}{*}{$\begin{array}{c}\text { Oblik } \\
\text { aproksimativne } \\
\text { teorijske krive } \\
\text { linije }\end{array}$} \\
\hline & \multirow{2}{*}{ 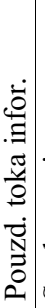 } & \multirow{2}{*}{\multicolumn{2}{|c|}{ 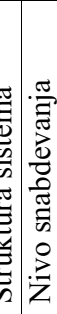 }} & \multirow[b]{2}{*}{ 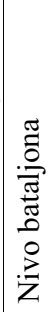 } & \multirow[b]{2}{*}{ 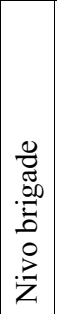 } & \multirow[b]{2}{*}{ 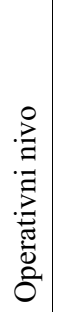 } & \multirow[b]{2}{*}{ 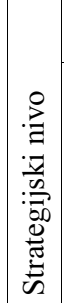 } & & & & & & & & & & \\
\hline & & & & & & & & 0,1 & 0,3 & 0,4 & 0,5 & 0,6 & 0,7 & 0,8 & 0,9 & 0,99 & \\
\hline 1 & 2 & 3 & 4 & 5 & 6 & 7 & 8 & 9 & 10 & 11 & 12 & 13 & 14 & 15 & 16 & 17 & 18 \\
\hline 1. & 6 & 1 & 1 & - & - & - & - & 338 & 354,6 & 363,6 & 366,4 & 377,4 & 373,4 & 382,8 & 385,8 & 386 & $\begin{array}{l}\text { polinom } \\
\text { 3. stepena }\end{array}$ \\
\hline 2. & 6 & 1 & 2 & - & 0,4 & 0,5 & 0,5 & 359,8 & 352 & 359,8 & 362 & 364,6 & 363,7 & 370,7 & 377,6 & 369,6 & $\begin{array}{l}\text { polinom } \\
\text { 2. stepena }\end{array}$ \\
\hline 3. & 6 & 1 & 3 & 0,2 & - & 0,5 & 0,5 & 352 & 354,4 & 357,8 & 361,5 & 366 & 378,9 & 373,8 & 376,4 & 380,8 & $\begin{array}{l}\text { polinom } \\
\text { 2. stepena }\end{array}$ \\
\hline 4. & 6 & 1 & 4 & 0,2 & 0,4 & - & 0,5 & 356,2 & 360,2 & 362,1 & 358,8 & 360,2 & 358,4 & 362,6 & 365,4 & 365 & $\begin{array}{l}\text { logaritamska } \\
\text { funkcija }\end{array}$ \\
\hline 5. & 6 & 1 & 5 & 0,2 & 0,4 & 0,5 & - & 356,2 & 354,2 & 358,5 & 353,4 & 358,8 & 359,6 & 361,8 & 363,2 & 367 & $\begin{array}{l}\text { eksponencijalna } \\
\text { funkcija }\end{array}$ \\
\hline 6. & 6 & 2 & 1 & - & - & - & - & 353,2 & 358,4 & 352,6 & 363,2 & 359,2 & 359,2 & 364,1 & 364,6 & 363,2 & $\begin{array}{l}\text { polinom } \\
\text { 3. stepena }\end{array}$ \\
\hline 7. & 6 & 2 & 2 & - & 0,4 & - & 0,7 & 344,8 & 351,4 & 354,6 & 359,4 & 356 & 367,2 & 369,6 & 367,4 & 366,8 & $\begin{array}{l}\text { polinom } \\
\text { 3. stepena }\end{array}$ \\
\hline 8. & 6 & 2 & 3 & 0,2 & - & - & 0,7 & 352,2 & 350,6 & 356,4 & 359 & 359,1 & 356,6 & 357,6 & 361,2 & 357 & $\begin{array}{l}\text { polinom } \\
\text { 3. stepena }\end{array}$ \\
\hline 9. & 6 & 2 & 4 & 0,2 & 0,4 & - & - & 350,2 & 351,6 & 349,7 & 360,6 & 357,4 & 359,2 & 360,1 & 358,5 & 357,3 & $\begin{array}{l}\text { polinom } \\
\text { 3. stepena }\end{array}$ \\
\hline
\end{tabular}

Prva kolona u tabeli označava grupu sprovedenih eksperimenata. Pripadnost grupi eksperimenata određena je sa sledeća tri elementa:

- pouzdanošću toka informacija. Informacija o tome da li je u eksperiment uključena verovatnoća gubljenja ili zaturanja informacija označena je cifrom $u$ koloni 2 (bez gubljenja ili zaturanja informacija -6 , sa gubljenjem ili zaturanjem informacija - 7);

- strukturom sistema snabdevanja rezervnim delovima koja je posmatrana, što je označeno cifrom u koloni 3 (četvo- ronivojska struktura -1 , tronivojska struktura -2);

- nivoom u posmatranoj strukturi sistema snabdevanja na kojem je vršena promena verovatnoće popunjenosti rezervnim delovima, što je označeno cifrom u koloni 4 (istovetno na svim nivoima -1 , na nivou bataljona -2 , na nivou brigade -3 , na operativnom nivou u četvoronivojskoj strukturi i na strategijskom nivou u tronivojskoj strukturi - 4, na strategijskom nivou u četvoronivojskoj strukturi-5).

U kolonama od 5 do 8 prikazane su parametarske vrednosti verovatnoće po- 
punjenosti rezervnim delovima na ostalim nivoima snabdevanja u sistemu. $U$ kolonama od 9 do 17 prikazane su srednje vrednosti broja ispravnih borbenih vozila u zavisnosti od vrednosti verovatnoće popunjenosti rezervnim delovima na posmatranom nivou snabdevanja i parametarskih vrednosti verovatnoće popunjenosti rezervnim delovima na ostalim nivoima u sistemu snabdevanja.

Odnos prikazanih srednjih vrednosti broja ispravnih borbenih vozila na kraju 12. dana borbenih dejstava i broja ispravnih borbenih vozila na početku borbenih dejstava pretvoren je u procentualni iznos, čime je dobijena gotovost borbenih vozila, prema navedenom određenju. Povezivanjem ovako dobijenih vrednosti gotovosti borbenih vozila za svaku vrednost verovatnoće popunjenosti rezervnim delovima, za svaku grupu eksperimenata dobijena je izlomljena kriva linija. Kako bi se prikazao trend gotovosti borbenih vozila u zavisnosti od verovatnoće popu- njenosti rezervnim delovima, izlomljena kriva linija aproksimirana je teorijskom neprekidnom krivom linijom (slika 1). $\mathrm{Na}$ osnovu teorijskih krivih linija izvršeno je međusobno upoređivanje gotovosti borbenih vozila $u$ zavisnosti od verovatnoće popunjenosti rezervnim delovima.

\section{Analiza uticaja strukture sistema snabdevanja rezervnim delovima}

Uticaj strukture sistema snabdevanja rezervnim delovima može se prikazati i objasniti rezultatima eksperimenata, pri kojima je vršena promena verovatnoće popunjenosti rezervnim delovima istovetno na svim nivoima, u tronivojskom i četvoronivojskom sistemu snabdevanja (slika 2). Na taj način minimizira se uticaj nivoa snabdevanja, a do izražaja dolazi uticaj strukture sistema snabdevanja rezervnim delovima.

Funkcija gotovosti borbenih vozila, pri promeni verovatnoće popunjenosti re-

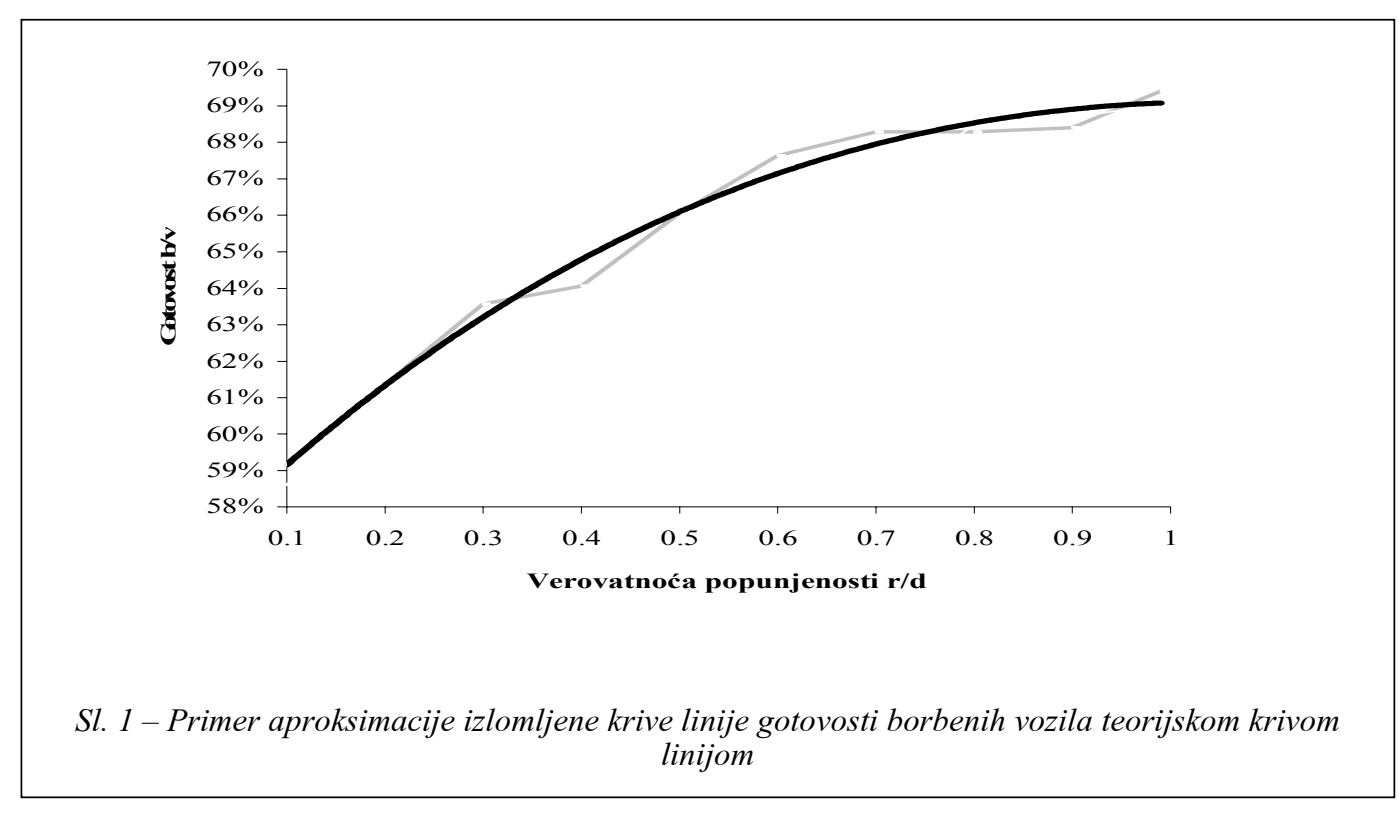




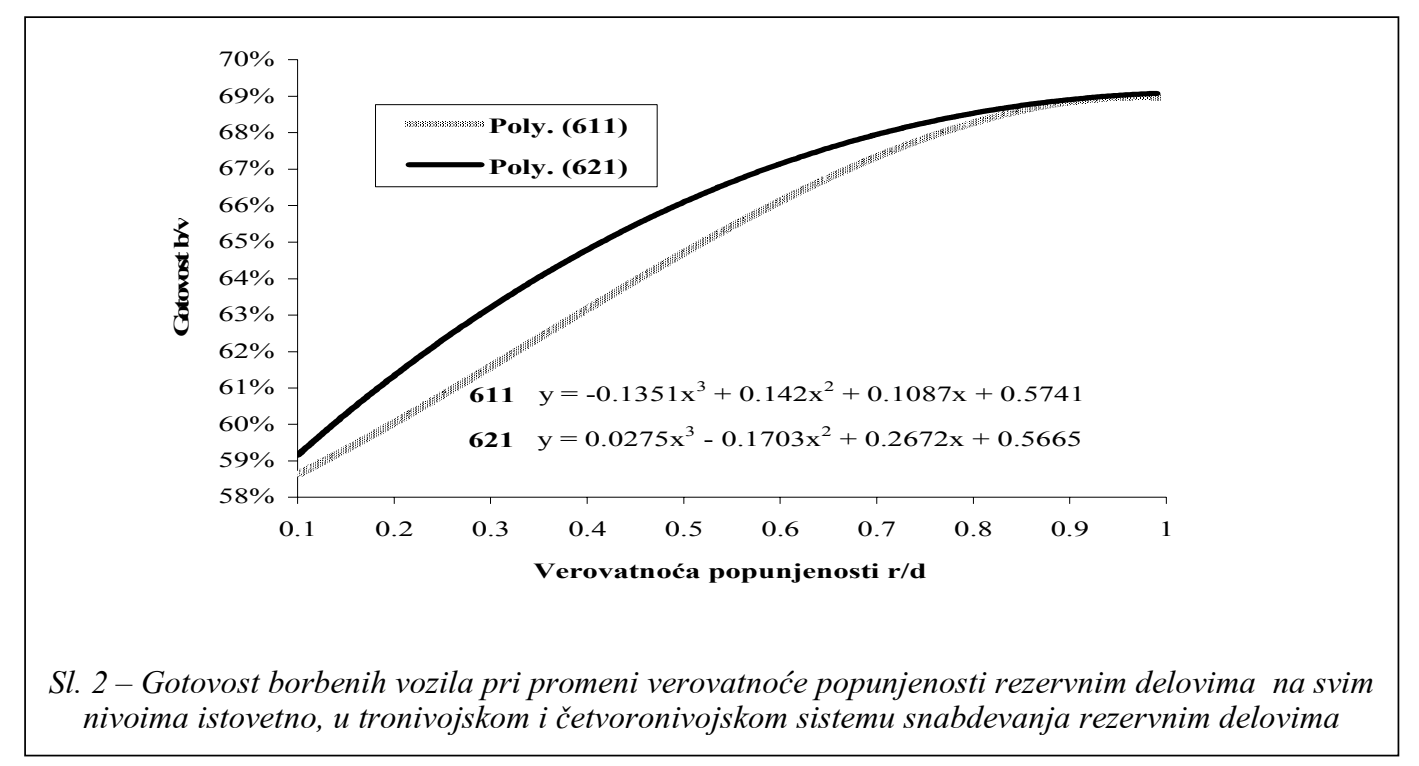

zervnim delovima istovetno na svim nivoima, $u$ četvoronivojskom sistemu snabdevanja, označena brojem 611, aproksimirana je teorijskom krivom $\mathrm{u}$ obliku polinoma trećeg stepena, kao i funkcija gotovosti borbenih vozila pri promeni verovatnoće popunjenosti rezervnim delovima istovetno na svim nivoima, u tronivojskom sistemu snabdevanja, označena brojem 621. Zapaža se da gotovost borbenih vozila ima veće vrednosti za sve vrednosti verovatnoće popunjenosti rezervnim delovima pri tronivojskom sistemu snabdevanja rezervnim delovima, osim u segmentu vrednosti verovatnoće popunjenosti rezervnim delovima iznad 0,8 , u kojem se razlika vrednosti gotovosti borbenih vozila bitno smanjuje. Već za vrednost verovatnoće popunjenosti 0,9 , teorijske krive gotovosti borbenih vozila, primenom tronivojskog i četvoronivojskog sistema snabdevanja rezervnim delovima, imaju jednake vrednosti.

Gotovost borbenih vozila, dobijena eksperimentom sa promenom verovatno- ce popunjenosti rezervnim delovima $u$ četvoronivojskom sistemu snabdevanja, za vrednost verovatnoće popunjenosti rezervnim delovima 0,1 , za $0,6 \%$ je manja od vrednosti gotovosti borbenih vozila dobijene eksperimentom sa promenom verovatnoće popunjenosti rezervnim delovima u tronivojskom sistemu snabdevanja. Razlika gotovosti je 3,1 borbenih vozila ili oko jedan oklopno-mehanizovani vod.

Sa porastom verovatnoće popunjenosti rezervnim delovima povećava se i razlika gotovosti borbenih vozila. Najveća je u segmentu verovatnoće popunjenosti između 0,3 i 0,4 i iznosi $1,6 \%$, što je 8,33 borbenih vozila ili nešto manje od 3 oklopno-mehanizovana voda. Razlika gotovosti je osetna do vrednosti verovatnoće popunjenosti rezervnim delovima 0,7 . Za veće vrednosti verovatnoće popunjenosti razlika gotovosti se smanjuje, a izjednačava za vrednosti verovatnoće popunjenosti rezervnim delovima iznad 0,9, kada dolazi do zasićenja obe teorijske 
krive gotovosti borbenih vozila. To znači da se sa povećanjem verovatnoće popunjenosti rezervnim delovima iznad 0,9 ne povećava gotovost borbenih vozila u borbenim dejstvima, bez obzira na to da li je primenjen tronivojski ili četvoronivojski sistem snabdevanja, odnosno, da pri visokim vrednostima verovatnoće popunjenosti rezervnim delovima uopšte nije bitno koji je sistem snabdevanja rezervnim delovima primenjen.

Upoređujući vrednosti verovatnoće popunjenosti rezervnim delovima, pri istim vrednostima gotovosti borbenih vozila u četvoronivojskom i tronivojskom sistemu snabdevanja rezervnim delovima, zapaža se da razlika verovatnoće popunjenosti rezervnim delovima isnosi 0,1 u segmentu od 0,3 do 0,6 , što ukazuje na to da se sa manjom verovatnoćom popunjenosti rezervnim delovima u tronivojskom sistemu snabdevanja može postići ista vrednost gotovosti borbenih vozila. To je vrlo bitno s obzirom na stvarnu snabdevenost rezervnim delovima u realnom sistemu snabdevanja. Uzimajući $u$ obzir broj nivoa snabdevanja rezervnim delovima može se zaključiti da se primenom tronivojskog sistema snabdevanja može ostvariti izvesna ušteda u zalihama rezervnih delova u odnosu na četvoronivojski sistem snabdevanja.

Razlika gotovosti borbenih vozila, $u$ segmentu verovatnoće popunjenosti rezervnim delovima od 0,1 do 0,8 , jasno ukazuje na prednosti koje ima tronivojski sistem snabdevanja rezervnim delovima. Razlika je najizraženija u segmentu verovatnoće popunjenosti rezervnim delovima kakva je u realnom sistemu snabdevanja. Očigledno je da eliminacija operativnog nivoa iz sistema snabdevanja rezervnim delovima ima izrazit pozitivan efekat.

\section{Uticaj pojedinačnih nivoa snabdevanja rezervnim delovima na gotovost borbenih vozila $u$ borbenim dejstvima}

Na slici 3 prikazani su grafički rezultati simulacije za eksperimente sa promenom verovatnoće popunjenosti rezer-

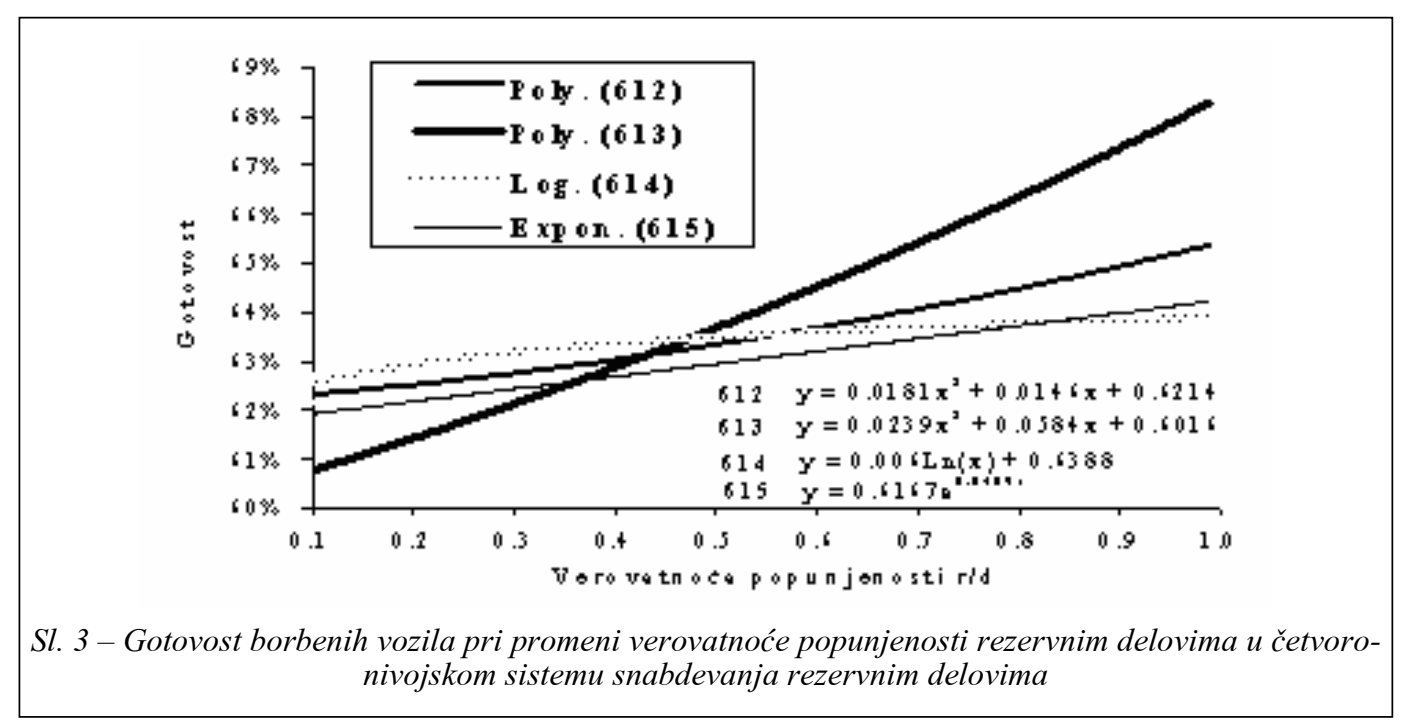


vnim delovima po nivoima snabdevanja $\mathrm{u}$ četvoronivojskom sistemu snabdevanja rezervnim delovima.

Funkcija gotovosti borbenih vozila, pri promeni verovatnoće popunjenosti rezervnim delovima na nivou bataljona, označena brojem 612, aproksimirana je teorijskom krivom u obliku polinoma drugog stepena. Vrednost gotovosti borbenih vozila pri verovatnoći popunjenosti rezervnim delovima 0,1 je $62,3 \%$, a pri verovatnoći popunjenosti 0,99 vrednost gotovosti je 65,4\%. Ukupna razlika gotovosti borbenih vozila za granične vrednosti verovatnoće popunjenosti 0,99 i 0,1 je $3,1 \%$, što je 16,1 borbenih vozila ili oko 1,5 oklopno-mehanizovana četa. Srednji prirast gotovosti borbenih vozila na segmentu verovatnoće popunjenosti rezervnim delovima od 0,1 do 0,5 je oko $0,2 \%$, pri promeni verovatnoće popunjenosti za 0,1 . Ukupna razlika gotovosti na tom segmentu je $1 \%$, što je 5,2 borbenih vozila ili oko dva oklopno-mehanizovana voda. Na segmentu verovatnoće popunjenosti od 0,5 do 0,99 razlika gotovosti je $2 \%$, što je 10,4 borbenih vozila ili nešto više od oklopno-mehanizovane čete.

Funkcija gotovosti borbenih vozila, pri promeni verovatnoće popunjenosti rezervnim delovima na nivou brigade, označena brojem 613, aproksimirana je teorijskom krivom u obliku polinoma drugog stepena. Vrednost gotovosti borbenih vozila pri verovatnoći popunjenosti rezervnim delovima 0,1 je $60,8 \%$, a pri verovatnoći popunjenosti rezervnim delovima 0,99 vrednost gotovosti je $68,3 \%$. Ukupna razlika gotovosti borbenih vozila za granične vrednosti verovatnoće popunjenosti 0,99 i 0,1 je $7,5 \%$, što je 39 borbenih vozila ili oko jedan oklopno-meha- nizovani bataljon. Srednji prirast gotovosti, pri promeni verovatnoće popunjenosti za 0,1 , na segmentu od 0,1 do 0,5 , jeste oko $0,7 \%$. Razlika gotovosti na tom segmentu je $2,9 \%$, što je 15,1 borbenih vozila ili oko 1,5 oklopno-mehanizovana četa. Na segmentu verovatnoće popunjenosti rezervnim delovima od 0,5 do 0,99 srednji prirast gotovosti je oko $0,9 \%$, a razlika gotovosti $4,7 \%$, što je 24,5 borbenih vozila ili oko 2,5 oklopno-mehanizovane čete.

Funkcija gotovosti borbenih vozila, pri promeni verovatnoće popunjenosti rezervnim delovima na operativnom nivou, označena brojem 614, aproksimirana je teorijskom krivom u obliku funkcije prirodnog logaritma. Vrednost gotovosti borbenih vozila pri verovatnoći popunjenosti rezervnim delovima 0,1 je $62,5 \%$, a pri verovatnoći popunjenosti 0,99 vrednost gotovosti je 63,9\%. Ukupna razlika gotovosti borbenih vozila za granične vrednosti verovatnoće popunjenosti 0,99 i 0,1 je $1,4 \%$, što je 7,3 borbenih vozila ili nešto više od dva oklopno-mehanizovana voda. Na segmentu verovatnoće popunjenosti od 0,1 do 0,4 razlika gotovosti je $0,8 \%$, što je 4,2 borbenih vozila ili nešto više od oklopno-mehanizovanog voda. Već iznad vrednosti verovatnoće popunjenosti 0,4 teorijska kriva gotovosti poprima gotovo konstantnu vrednost. Srednji prirast gotovosti na tom segmentu verovatnoće popunjenosti je oko $0,08 \%$, pri promeni verovatnoće popunjenosti za 0,1 , a razlika gotovosti je $0,5 \%$, što je 2,6 borbenih vozila ili nešto manje od oklopno-mehanizovanog voda.

Funkcija gotovosti borbenih vozila pri promeni verovatnoće popunjenosti rezervnim delovima na strategijskom nivou, 
označena brojem 615, aproksimirana je teorijskom krivom u obliku eksponencijalne funkcije prirodne osnove. Vrednost gotovosti borbenih vozila pri verovatnoći popunjenosti rezervnim delovima 0,1 je $61,9 \%$, a pri verovatnoći popunjenosti rezervnim delovima 0,99 vrednost gotovosti je $64,25 \%$. Ukupna razlika gotovosti je $2,35 \%$ pri verovatnoći popunjenosti $0,99 \mathrm{i}$ 0,1 , što je 11,9 borbenih vozila ili nešto više od jedne oklopno-mehanizovane čete. Ne može se izdvojiti ni jedan segment verovatnoće popunjenosti rezervnim delovima na kojem ima bitne promene u rastu gotovosti borbenih vozila. Pri promeni verovatnoće popunjenosti rezervnim delovima za 0,1 srednji prirast gotovosti borbenih vozila je $0,25 \%$.

Međusobni odnos uticaja snabdevenosti nivoa snabdevanja na gotovost borbenih vozila slikovito se može prikazati ukoliko se posmatra razlika gotovosti pri verovatnoći popunjenosti rezervnim delovima 0,99 i 0,1 . U odnosu na snabdevenost rezervnim delovima na nivou bataljona uticaj snabdevenosti na nivou brigade je 2,41 puta izraženiji. U odnosu na snabdevenost na operativnom nivou uticaj snabdevenosti na nivou brigade je 5,3 puta izraženiji, a u odnosu na snabdevenost na strategijskom nivou, uticaj snabdevenosti rezervnim delovima na nivou brigade je 3,26 puta izraženiji.

Značaj popunjenosti rezervnim delovima na taktičkom nivou, odnosno na nivou brigade i na nivou bataljona, na gotovost borbenih vozila vrlo je izražen u odnosu na značaj popunjenosti rezervnim delovima na operativnom i strategijskom nivou, iz jednostavnog razloga što je u modelu nastajanja gubitaka generisan, $u$ relativnom odnosu, veći broj otkaza i oštećenja koji se mogu otkloniti realizacijom radova nivoa LR, nego što je broj otkaza i oštećenja koji se mogu otkloniti realizacijom radova nivoa SR i GR. Osim toga, vreme potrebno za realizaciju radova nivoa LR na nivou bataljona (do $6 \mathrm{~h}$ ) $\mathrm{i}$ na nivou brigade (do $24 \mathrm{~h}$ ) višestruko je kraće od vremena realizacije radova nivoa SR (24 do 150 h) i GR (80 do 600 h) [1].

Eksperimenti sa promenom verovatnoće popunjenosti rezervnim delovima na operativnom i na strategijskom nivou imaju približne vrednosti gotovosti borbenih vozila, pri čemu međusobna razlika ne prelazi $0,7 \%$, za sve vrednosti verovatnoće popunjenosti rezervnim delovima.

Na slici 4 prikazani su grafički rezultati simulacije za eksperimente sa promenom verovatnoće popunjenosti rezervnim delovima po nivoima snabdevanja $\mathrm{u}$ tronivojskom sistemu snabdevanja rezervnim delovima.

Funkcija gotovosti borbenih vozila pri promeni verovatnoće popunjenosti rezervnim delovima na nivou bataljona, označena brojem 622, aproksimirana je teorijskom krivom u obliku polinoma trećeg stepena. Vrednost gotovosti borbenih vozila pri verovatnoći popunjenosti rezervnim delovima 0,1 je $62,8 \%$, a pri verovatnoći popunjenosti rezervnim delovima 0,99 vrednost gotovosti je $67,1 \%$. Ukupna razlika gotovosti borbenih vozila je $4,3 \%$, pri vrednostima verovatnoće popunjenosti rezervnim delovima 0,99 i 0,1 , što je 22,4 borbenih vozila ili nešto više od dve oklopno-mehanizovane čete. Funkcija gotovosti borbenih vozila ima blagi rast za vrednosti verovatnoće popu- 


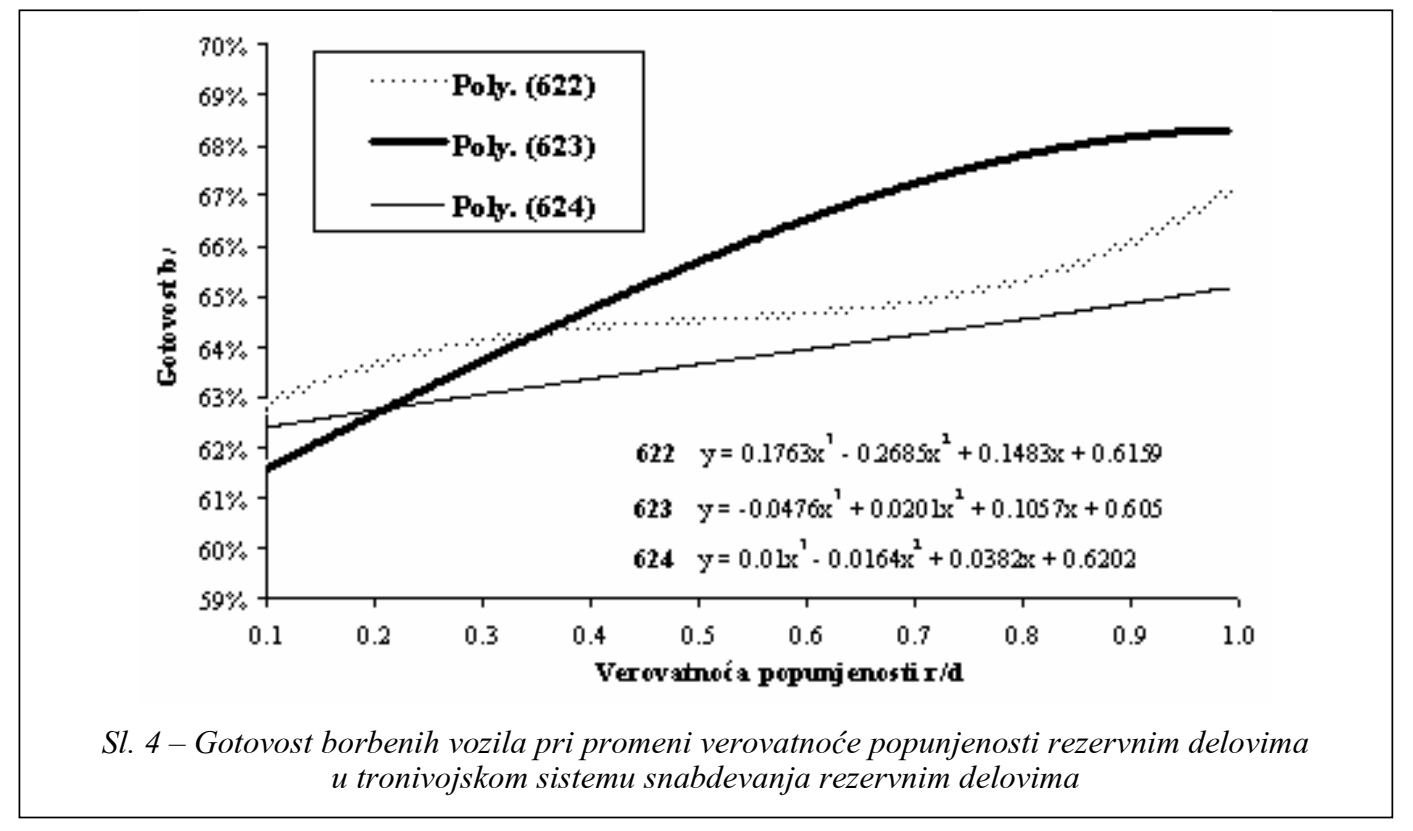

njenosti rezervnim delovima $u$ segmentu od 0,1 do 0,35 . Prirast gotovosti na tom segmentu je oko $0,35 \%$ pri promeni verovatnoće popunjenosti za 0,1 , dok je ukupna razlika gotovosti na tom segmentu oko $1,4 \%$, što je 7,3 borbenih vozila ili nešto više od dva oklopno-mehanizovana voda. U segmentu verovatnoće popunjenosti rezervnim delovima od 0,35 do 0,7 funkcija gotovosti ima tačku infleksije. Razlika gotovosti borbenih vozila na tom segmentu verovatnoće popunjenosti rezervnim delovima je $0,5 \%$, što je 2,6 borbenih vozila ili nešto manje od jednog oklopno-mehanizovanog voda. Izrazit rast gotovosti počinje od vrednosti verovatnoće popunjenosti 0,7 , pa je razlika gotovosti borbenih vozila $2,4 \%$ za vrednosti verovatnoće popunjenosti rezervnim delovima 0,99 i 0,7 .

Funkcija gotovosti borbenih vozila pri promeni verovatnoće popunjenosti rezervnim delovima na nivou brigade, označena brojem 623, aproksimirana je teorijskom krivom u obliku polinoma trećeg stepena. Vrednost gotovosti borbenih vozila pri verovatnoći popunjenosti rezervnim delovima 0,1 je $61,6 \%$, a pri verovatnoći popunjenosti rezervnim delovima 0,99 vrednost gotovosti je 68,3\%. Ukupna razlika gotovosti je $6,7 \%$, što je 34,9 borbenih vozila ili više od tri oklopno-mehanizovane čete.

Funkcija gotovosti borbenih vozila ima izražen rast za vrednosti verovatnoće popunjenosti na segmentu od 0,1 do 0,8 . Na tom segmentu razlika gotovosti je $6,2 \%$, što je 32,3 borbenih vozila ili nešto više od tri oklopno-mehanizovane čete. Srednji prirast gotovosti je oko $0,6 \%$, pri promeni verovatnoće popunjenosti za 0,1 . Iznad vrednosti verovatnoće popunjenosti rezervnim delovima 0,8 , teorijska kriva ima vrlo mali prirast. Na segmentu verovatnoće popunjenosti rezervnim delovima od 0,8 do 0,99 razlika gotovosti bor- 
benih vozila je $0,5 \%$, što je 2,6 borbenih vozila ili nešto manje od jednog oklopno-mehanizovanog voda.

Funkcija gotovosti borbenih vozila pri promeni verovatnoće popunjenosti rezervnim delovima na strategijskom nivou, označena brojem 624, aproksimirana je teorijskom krivom u obliku polinoma trećeg stepena. Vrednost gotovosti borbenih vozila pri verovatnoći popunjenosti rezervnim delovima 0,1 je $62,4 \%$, a pri verovatnoći popunjenosti rezervnim delovima 0,99 vrednost gotovosti je $65,2 \%$. Ukupna razlika gotovosti je $2,8 \%$, što je 14,5 borbenih vozila ili oko 1,5 oklopno-mehanizovana četa. Funkcija gotovosti borbenih vozila ima stalni blagi rast i ne može se izdvojiti ni jedan segment verovatnoće popunjenosti rezervnim delovima na kojem ima bitne promene u rastu. Srednji prirast gotovosti je oko $0,3 \%$ pri promeni verovatnoće popunjenosti za 0,1 .

Upoređujući razliku gotovosti borbenih vozila po ovim eksperimentima može se zaključiti da najveći uticaj na gotovost borbenih vozila ima snabdevenost rezervnim delovima na nivou brigade. U odnosu na snabdevenost rezervnim delovima na nivou bataljona, uticaj snabdevenosti rezervnim delovima na nivou brigade je 1,55 puta izraženiji, a u odnosu na snabdevenost na strategijskom nivou izraženiji je 2,39 puta.

\section{Zaključak}

Da bi se istražio uticaj snabdevenosti rezervnim delovima na ispravnost borbenih vozila u borbenim dejstvima, bilo je neophodno analizirati uticaj strukture sistema snabdevanja, tronivojske i četvoronivojske, uticaj svakog nivoa snabdevanja i uticaj snabdevenosti rezervnim delovima svakog nivoa snabdevanja. Izvršeno je eksperimentisanje na razvijenom simulacionom modelu održavanja, izvlačenja i evakuacije u borbenim dejstvima, prema planu eksperimenta. Rezultati eksperimenata predstavljaju statistički obrađen broj ispravnih borbenih vozila na kraju 12. dana borbenih dejstava, a prikazani su u grafičkoj formi pogodnoj za analiziranje uticaja navedenih faktora sistema snabdevanja rezervnim delovima.

Iz sprovedenog istraživanja može se zaključiti da:

- tronivojski sistem snabdevanja rezervnim delovima, u svim izvedenim eksperimentima, daje veću gotovost borbenih vozila $u$ borbenim dejstvima $u$ odnosu na četvoronivojski sistem snabdevanja;

- isti nivo gotovosti borbenih vozila može se postići manjim zalihama rezervnih delova, primenom tronivojskog sistema snabdevanja, nego što je to potrebno primenom četvoronivojskog sistema snabdevanja rezervnim delovima;

- snabdevenost rezervnim delovima na taktičkom nivou ima presudan uticaj na ispravnost borbenih vozila u borbenim dejstvima;

- snabdevenost rezervnim delovima na nivou brigade ima najveći uticaj na ispravnost borbenih vozila u borbenim dejstvima;

- povećanje snabdevenosti rezervnim delovima na taktičkom nivou snabdevanja ima neuporedivo veći uticaj na ispravnost borbenih vozila u borbenim dejstvima nego povećanje snabdevenosti rezervnim delovima viših nivoa snabdevanja; 
- istovetna popunjenost rezervnim delovima na svim nivoima snabdevanja obezbeđuje veću gotovost borbenih vozila u oba primenjena sistema snabdevanja, ali samo pri verovatnoći popunjenosti rezervnim delovima iznad 0,4 ;

- kada je snabdevenost rezervnim delovima vrlo visoka nije bitno koji sistem snabdevanja je primenjen - tronivojski ili četvoronivojski;

- verovatnoća popunjenosti rezervnim delovima iznad 0,8 nema ekonomskog opravdanja, jer se daljim povećanjem zaliha ne povećava gotovost borbenih vozila.

Rezultati istraživanja nedvosmisleno pokazuju da bi se uvođenjem tronivojskog sistema snabdevanja rezervnim delovima postigla veća gotovost borbenih vozila u borbenim dejstvima, što bi moglo intenzivirati istraživanja na polju projektovanja sistema snabdevanja rezervnim delovima i u operativnom upravljanju sistemom.

U narednim istraživanjima bilo bi neophodno odrediti asortiman rezervnih delova za reprezente borbenih vozila, koji bi se čuvao na pojedinim nivoima snabdevanja, u skladu sa nadležnostima svakog nivoa u sistemu održavanja. S obzirom na istražen uticaj verovatnoće po- punjenosti rezervnim delovima svakog nivoa snabdevanja, asortiman rezervnih delova uslovljen je željenim nivoom gotovosti borbenih vozila u borbenim dejstvima. Pri određivanju asortimana težište bi trebalo da bude na onim rezervnim delovima koji ispoljavaju direktan uticaj na gotovost borbenih vozila, što je presudno za period borbenih dejstava.

Uvođenjem tronivojskog sistema snabdevanja nastali bi izvesni troškovi, kao posledica nužnih preformacija pojedinih ustanova i skladišta rezervnih delova. Međutim, kako bi se tada celokupne rezerve rezervnih delova informatički objedinile, predislokacija postojećih skladišta sa sadašnjih lokacija ne bi bila neophodna.

Literatura:

[1] Stanojević, P.; Bukvić, V.; Mišković, V.: Model za simulaciju sistema održavanja, izvlačenja i evakuacije u borbenim dejstvima, studija, Vojnotehnička akademija VJ, Beograd, 1999.

[2] Đukić, D.: Uticaj snabdevenosti rezervnim delovima na ispravnost borbenih vozila u borbenim dejstvima, magistarski rad, Vojna akademija, Beograd, 2003.

[3] Mišković, V.; Bukvić, V.; Stanojević, P.: Kvantifikacija oblik uticaja snabdevenosti rezervnim delovima na ispravnost tehničkih sistema, Vojnotehnički glasnik, 2/2003.

[4] Stanojević, P.: Uticaj tehničkih faktora na organizacionu strukturu sistema održavanja, doktorska disertacija, Univerzitet u Beogradu, Mašinski fakultet, Beograd, 1997.

[5] Stanojević, P.; Bukvić, V.; Mišković, V.: Osnovna analiza karakteristika predloženog varijantnog rešenja organizacije održavanja materijalnih sredstava, studija, Vojnotehnička akademija VJ, Beograd, 2000. 